\title{
Impact of the COVID-19 pandemic on food fraud vulnerability in food supply networks
}

Saskia M. van Ruth ${ }^{1}$

${ }^{1}$ Wageningen Food Safety Research, P.O. Box 230, 6700 AE Wageningen, the Netherlands

This research has been carried out by Wageningen Food Safety Research, institute within the legal entity Wageningen Research Foundation subsidised by the Dutch Ministry of Agriculture, Nature and Food Quality (project number WOT-02-005-044).

Wageningen, October 2020

WFSR report 2020.017 
van Ruth, S. M., 2020. Impact of the COVID-19 pandemic on food fraud vulnerability in food supply networks. Wageningen, Wageningen Food Safety Research, WFSR report 2020.017. 26 pp.; 3 fig.; 3 tab.; 22 ref.

Project number: WOT-02-005-044

BAS-code: WOT-02-005-044

Project title: Food fraud

Project leader: Prof. dr ir S.M. van Ruth

This report can be downloaded for free at https://doi.org/10.18174/536459 or at www.wur.eu/foodsafety-research (under WFSR publications).

(c) 2020 Wageningen Food Safety Research, institute within the legal entity Wageningen Research Foundation. Hereinafter referred to as WFSR.

The client is allowed to publish or distribute the full report to third parties. Without prior written permission from WFSR it is not allowed to:

a) publish parts of this report;

b) use this report or title of this report in conducting legal procedures, for advertising, acquisition or other commercial purposes;

c) use the name of WFSR other than as the author of this report.

P.O. Box 230, 6700 AE Wageningen, The Netherlands, T +31 (0)317 4802 56, E info.wfsr@wur.nl, www.wur.eu/food-safety-research. WFSR is part of Wageningen University \& Research.

This report from WFSR has been produced with the utmost care. However, WFSR does not accept liability for any claims based on the contents of this report. 


\section{Contents}

Contents

$\begin{array}{lr}\text { Summary } & 5\end{array}$

1

Background and aim of the study

Baseline fraud vulnerabilities in food industry segments

8

3

General impact of the COVID-19 pandemic on individual food fraud risk factors

Merging baseline fraud vulnerabilities in industry segments with expected impact of the COVID-19 pandemic 


\section{Summary}

The COVID-19 pandemic and related containment measures have placed food supply chains under great pressure. They have led to disruptions in supply and demand of food products but also led to shortfall in staff in various places affecting production, logistics, and adequacy of controls. Any disturbance in routine practices affects crime and criminal behaviour as has been conceptualised by the criminological Routine Activities Theory. Therefore, an effect of the pandemic on food fraud risk and prevalence may be expected. In the current study we examined the impact of the COVID-19 pandemic on food fraud vulnerabilities of European food businesses by conceptualising its effect on 50 food fraud risk factors identified previously using a theoretical framework analogue to the Routine Activities Theory. To identify the baseline vulnerabilities of industry segments, empirical fraud vulnerability assessment data from fish, meat, olive oil, spices, and various organic supply chains from previous studies were collated. Conventional and organic olive oil, meat, and spices appear industry segments with an intrinsically higher level of food fraud vulnerability. The impact of the COVID-19 pandemic on individual food fraud risk factors reveals primarily an enhancing effect on the economic and cultural/behavioural drivers as well as a reduction in adequacy of control measures. The pandemic has less impact on opportunities. When focusing on the individual industry segments, all are impacted in a negative sense. Even so, fish and meat industry segments see most widely spread effects in terms of production, logistics, and demand. These disruptions affect, in turn, in particular economic and cultural/behavioural drivers. Consequently, food fraud vulnerability of these animal production chain networks, which was already relatively high prior to the pandemic, appear to have further increased due to the COVID-19 pandemic. 


\section{Background and aim of the study}

Food fraud is defined in the EU as 'any suspected intentional action by businesses or individuals for the purpose of deceiving purchasers and gaining undue advantage therefrom, in violation of the rules referred to in Article 1(2) of Regulation (EU) 2017/625 (the agri-food chain legislation). It is as old as mankind and reaches to every dinner table in the world. Over the last decades food supply chains have become longer and more complex due to globalisation. Frauds, committed close-by and yesterday or thousands of kilometres away and months or more ago, impact on businesses and consumers in the EU. Some businesses in food supply chain networks are offenders themselves, others are victimized by others at prior steps in the chain and pass on illicit products unknowingly. These intentional infringements lead to unfair competition but may also constitute a risk to human, animal and plant health, to animal welfare or to the environment. Many cases have surfaced over the last decades but the melamine incident in China in 2009 (Wu et al., 2009) and the horsemeat affair in the EU in 2013 (Robson et al., 2020) represented strikingly unfavourable highlights.

To address a problem, it needs to be comprehended by disassembling the various factors that play a role. For that matter, we conceptualised food fraud (van Ruth et al., 2017) using a framework which is an analogue to the well-recognised criminological Routine Activities Theory (Cohen and Felson, 1979). This theory uses the elements 'the motivated offender', 'the suitable target', and 'the lack of guardianship' to explain crimes and criminal behaviour. Fifty risk factors that affect food fraud vulnerability of individual businesses in food supply chain networks have been identified with evidence from both natural and social sciences. The approach has been implemented into an assessment for supply chain actors allowing them to gauge their food fraud vulnerabilities and develop control plans. The assessment has been widely used with over 70,000 downloads world-wide (SSAFE, 2020) but has also been applied in scientific studies. This has resulted in an overview of the differences in fraud vulnerability resulting from this set of risk factors for industry segments, tiers, geographical locations, and business size groups.

The emergence of the COVID-19 pandemic and related measures has placed supply chains under great pressure. It has tremendously affected operations but also the fraud risks that businesses face. Issues include CEO fraud, fraudulent products and services, insolvency fraud, phishing and other information security threats, and misappropriation of assets and theft (Deloitte, 2020). Considering that COVID-19 has also interrupted food supply chain operations considerably, the pandemic is likely to have affected food fraud risks as well.

In the current study, we explore the impact of the COVID-19 pandemic on food fraud vulnerabilities of European food businesses by conceptualising its effect on the individual 50 fraud risk factors of the above described criminology-based theoretical framework. As a starting point empirical assessment data from businesses in various supply chains are presented as the baseline food fraud vulnerabilities for different food industry segments. Secondly, general shifts in vulnerability levels are hypothesized for each risk factor. Subsequently, where feasible, we examine which industry segments are expected to be affected most by distinguishing the degree of changes expected for each commodity chain. Finally, these effects are evaluated while balancing for the baseline food fraud vulnerabilities of the segments. 


\section{Baseline fraud vulnerabilities in food industry segments}

The fraud vulnerabilities of processors in the regular fish, meat (beef), milk, and olive oil supply chains as well as in organic banana, egg, meat (pork), and olive oil productions were compared from data acquired in previous studies (Silvis et al., 2017; van Ruth et al., 2018; van Ruth et al., 2020; Yan et al., 2020; Yang et al., 2020). The mode for each risk factor and industry segment was calculated and is listed in Annex 1. Subsequently, the modes of the appropriate risk factors were cumulated for opportunities, motivations, drivers and enablers (opportunities + motivations), and controls. The first two are graphically presented in Figure 2.1 and the latter in Figure 2.2. The arrows towards the right hand side upper corners indicate the increase in food fraud vulnerability. Regarding the opportunities and motivations, it is noted that meat, (organic) olive oil, and spices score high in terms of vulnerability resulting from both opportunities and motivations. On the other hand, organic bananas score relatively low for both elements. The other segments score in between. When considering the controls as well (Figure 2.2), (organic) olive oil and spices still score high in vulnerability, but the meat industry reports more adequate controls than other segments. Summed modes for controls show limited variation across the segments, but summed modes vary considerably more for the drivers and enablers (opportunities + motivations).

As a matter of fact, from these results industry segments with intrinsically more or fewer vulnerabilities can be identified. In this respect, regular and organic olive oil show more vulnerabilities as well as spices and meat, whereas milk and organic bananas show fewer. These differences result predominantly from differences in levels of opportunities and motivations, with the latter including economic and cultural/behavioural drivers. In the following sections, the impact of COVID-19 on the individual fraud risk factors is determined. 


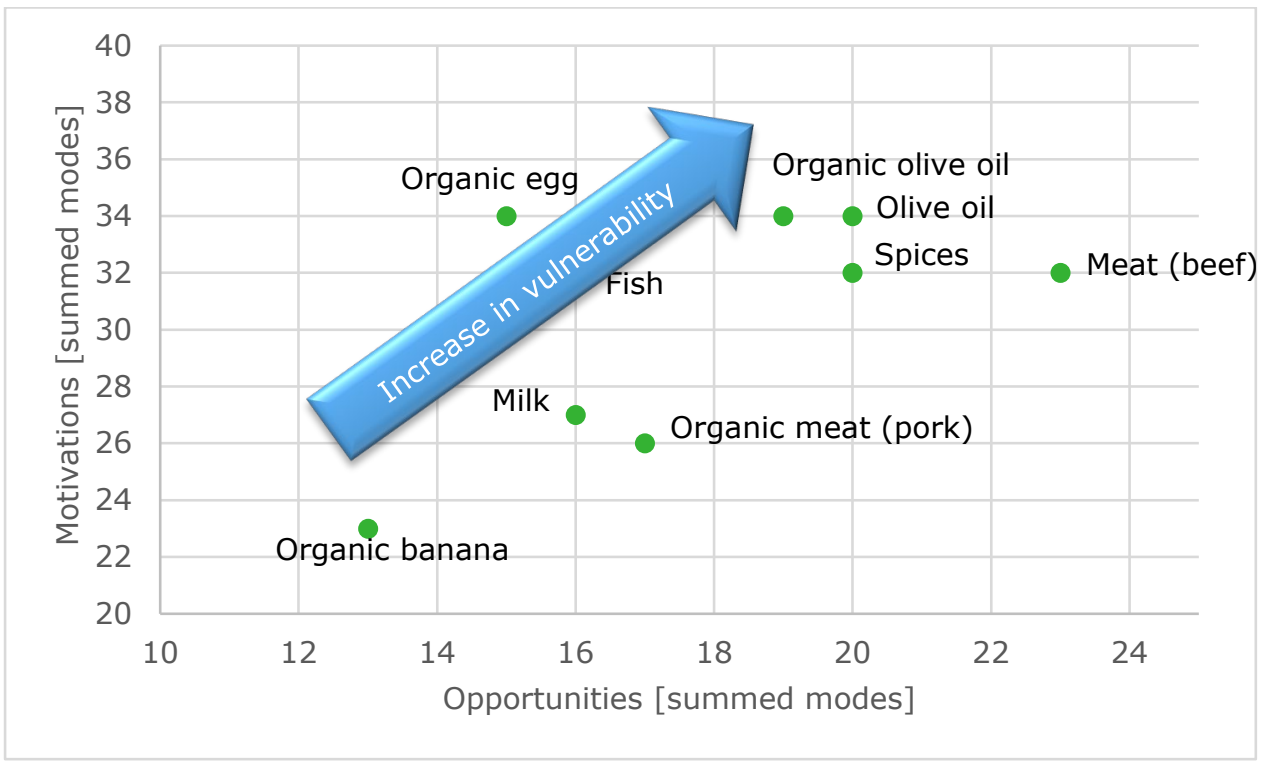

Figure 2.1 Food fraud vulnerability levels for drivers and enablers in various food industries represented for opportunities (horizontal) and motivations (vertical): Summed modes for individual fraud risk factor, raw data is listed in Annex 1. Higher scores reflect higher vulnerability.

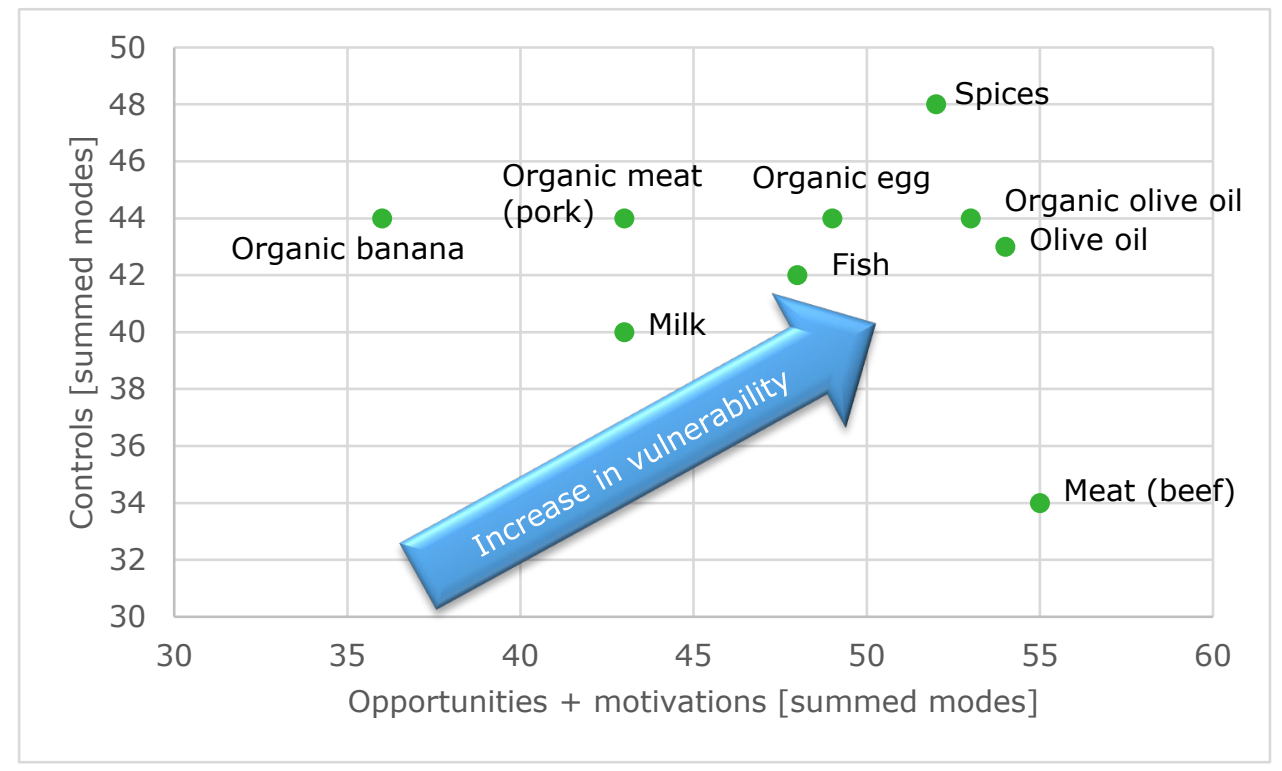

Figure 2.2 Food fraud vulnerability levels for drivers and enablers (horizontal) and controls (vertical) in various food industries: Summed modes for individual fraud risk factors, raw data listed in Annex 1. Higher scores reflect higher vulnerability. 


\section{General impact of the COVID-19 pandemic on individual food fraud risk factors}

For each of the individual food fraud risk factors of the Food Fraud vulnerability Assessment (FFVA), the extent of influence of the COVID-19 pandemic was examined. Results are presented in Table 3.1. Firstly, the six food fraud risk factor categories (technical opportunities, opportunities in time and place, economic drivers, cultural and behavioural drivers, technical controls, managerial controls) will be discussed and subsequently the results interpreted at a higher level of abstraction.

\section{Fraud risk factor categories}

None of the risk factors related to technical opportunities are expected to be impacted by the pandemic. This is due to the fact that the technical opportunities relate directly to intrinsic product properties or the general detectability of these properties. Those do not change because of a pandemic. The second category, opportunities in time and place, is more affected: For two out of the four factors an increase in vulnerability level is noted. This concerns the access to production lines/processing activities due to labour shortage on site as workers were urged to stay at home and also because of social distancing. Furthermore, the transparency in the chain network generally decreased due to necessary changes in routes in these networks due to supply chain and market interruptions. Regarding economic drivers, the vulnerability levels of many factors are affected (five out of seven, $\sim 70 \%)$. For instance, the supply and pricing of raw materials, the economic health of businesses, as well as the competition levels are affected. This is the result of the impact of the COVID-19 pandemic on production, demand, supply chain and market interruptions, as well as the financial impact on firms and financial markets. In the category 'cultural and behavioural drivers', vulnerability levels of four out of 13 factors $(\sim 30 \%)$ are expected to increase. Organisational strategies may change towards a survival mode with more focus on short-term goals and loosening of ethical restrictions. Finally, due to change in supply chain structures, as a result of disruptions, suppliers may be selected with fewer restrictions when it comes to the corruption level of the country a supplier is operating in. This kind of situations may have been avoided under normal circumstances. The application of technical means to control food fraud are likely to deteriorate and come second in these strenuous conditions because many will focus on survival and safety first, it is expected that 6 out of the 11 fraud factors will see enhanced vulnerability levels ( $55 \%)$. Sampling and analyses may be interrupted due to the urge of staff to work from home and due to infections of staff. Regarding managerial controls, vulnerability levels of 6 out of 8 factors are expected to increase $(\sim 75 \%)$. The reduction of intra- and inter-company contacts and altered priorities may interrupt integrity screening and whistle-blowing programs as well as social control in the chain. Contractual requirements imposed on suppliers may be tightened because of companies' own economic health. Finally, law enforcement is also affected by infection rates, social distancing, working from home policies, and shifts in priorities.

\section{Consequences}

To summarise the expected impact of the COVID-19 pandemic on individual food fraud risk factors it is noted that nearly half of the food fraud factors (23 out of the 48) listed in Table 3.1 are expected to present increased levels of vulnerability. In regard to the drivers and enablers, in particular altered motivations will drive the enhanced fraud vulnerability. Opportunities change to a lesser extent due to the pandemic. On the other hand, also the counteracting controls are expected to be considerably weakened during the pandemic, which holds for both the technical and managerial controls. As a consequence, food fraud risks are expected to be considerably increased during the pandemic because of (a) the increased stimulus from fraud drivers and (b) reduced adequacy of control measures. 
Table 3.1 Changes in vulnerability of individual food fraud risk factors expected from the COVID-19 pandemica.

\begin{tabular}{|c|c|c|c|c|c|c|}
\hline $\begin{array}{l}\text { Fraud } \\
\text { risk } \\
\text { factor } \\
\text { category }\end{array}$ & $\begin{array}{l}\text { Fraud risk } \\
\text { factor } \\
\text { number }\end{array}$ & Fraud risk factor & $\begin{array}{l}\text { General change due to } \\
\text { CoVID-19 outbreak }\end{array}$ & Justification & $\begin{array}{l}\text { Number of risk } \\
\text { factors affected per } \\
\text { fraud risk factor } \\
\text { category }(\%)\end{array}$ & $\begin{array}{l}\text { Number of risk } \\
\text { factors affected per } \\
\text { fraud risk key } \\
\text { element }(\%)\end{array}$ \\
\hline \multirow{5}{*}{ 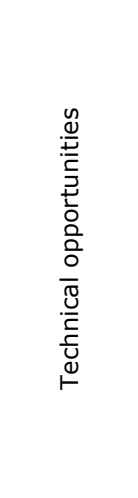 } & 1 & Complexity adulteration raw materials & No change & $\begin{array}{l}\text { Characteristics of product does not change } \\
\text { due to COVID- } 19\end{array}$ & \multirow{5}{*}{$0 / 5(0 \%)$} & \multirow{9}{*}{$2 / 9(22 \%)$} \\
\hline & 2 & $\begin{array}{l}\text { Availability of technology and } \\
\text { knowledge to adulterate raw materials }\end{array}$ & No change & $\begin{array}{l}\text { Availability of technology or knowledge does } \\
\text { not change due to COVID-19 }\end{array}$ & & \\
\hline & 3 & Fraud detectability in raw materials & No change & $\begin{array}{l}\text { General detectability does not change due to } \\
\text { COVID- } 19\end{array}$ & & \\
\hline & 4 & $\begin{array}{l}\text { Availability of technology and } \\
\text { knowledge to adulterate final products }\end{array}$ & No change & $\begin{array}{l}\text { Availability of technology or knowledge does } \\
\text { not change due to COVID-19 }\end{array}$ & & \\
\hline & 5 & Fraud detectability in final products & No change & $\begin{array}{l}\text { General detectability does not change due to } \\
\text { COVID-19 }\end{array}$ & & \\
\hline \multirow{4}{*}{ 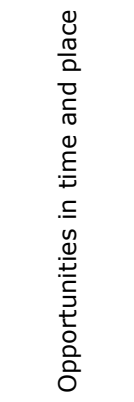 } & 8 & $\begin{array}{l}\text { Access to production lines/processing } \\
\text { activities }\end{array}$ & Increased vulnerability & $\begin{array}{l}\text { Fewer employees and management present; } \\
\text { social distancing }\end{array}$ & \multirow{4}{*}{$2 / 4(50 \%)$} & \\
\hline & 9 & Transparency in the chain network & Increased vulnerability & $\begin{array}{l}\text { Transparency reduced, change in supply } \\
\text { networks due to changes in supply, less } \\
\text { information exchange }\end{array}$ & & \\
\hline & 10 & $\begin{array}{l}\text { Historical evidence of fraud in raw } \\
\text { materials }\end{array}$ & No change & $\begin{array}{l}\text { Historical evidence does not change due to } \\
\text { COVID-19 }\end{array}$ & & \\
\hline & 11 & $\begin{array}{l}\text { Historical evidence of fraud in final } \\
\text { products }\end{array}$ & No change & $\begin{array}{l}\text { Historical evidence does not change due to } \\
\text { COVID-19 }\end{array}$ & & \\
\hline \multirow{2}{*}{ 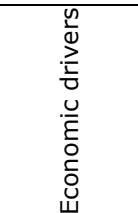 } & 12 & Supply and pricing raw materials & Increased vulnerability & $\begin{array}{l}\text { Supplies interrupted, price spikes due to } \\
\text { limited supply of certain products }\end{array}$ & \multirow{2}{*}{$5 / 7(71 \%)$} & \\
\hline & 13 & Valuable components or attributes & No change & $\begin{array}{l}\text { Product characteristics do not change due to } \\
\text { COVID-19 }\end{array}$ & & \\
\hline
\end{tabular}




\begin{tabular}{|c|c|c|c|c|c|c|}
\hline $\begin{array}{l}\text { Fraud } \\
\text { risk } \\
\text { factor } \\
\text { category }\end{array}$ & $\begin{array}{l}\text { Fraud risk } \\
\text { factor } \\
\text { number }\end{array}$ & Fraud risk factor & $\begin{array}{l}\text { General change due to } \\
\text { Covid-19 outbreak }\end{array}$ & Justiffication & $\begin{array}{l}\text { Number of risk } \\
\text { factors affected per } \\
\text { fraud risk factor } \\
\text { category }(\%)\end{array}$ & $\begin{array}{l}\text { Number of risk } \\
\text { factors affected per } \\
\text { fraud risk key } \\
\text { element (\%) }\end{array}$ \\
\hline & 14 & Economic health of own company & Increased vulnerability & Some businesses in economic problems & & \multirow{12}{*}{$9 / 20(45 \%)$} \\
\hline & 20 & Economic health of supplier & Increased vulnerability & Some businesses in economic problems & & \\
\hline & 26 & Economic health of sector & Increased vulnerability & Some businesses in economic problems & & \\
\hline & 30 & $\begin{array}{l}\text { Level of competition in branch of } \\
\text { industry }\end{array}$ & Increased vulnerability & $\begin{array}{l}\text { When supply and demand change, } \\
\text { competition is affected }\end{array}$ & & \\
\hline & 31 & Price asymmetries & No change & $\begin{array}{l}\text { Asymmetries are dictated by the chain and is } \\
\text { not expected to be considerably affected by } \\
\text { COVID-19 }\end{array}$ & & \\
\hline \multirow{7}{*}{ 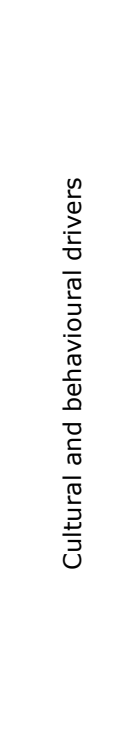 } & 15 & Organizational strategy of own company & Increased vulnerability & $\begin{array}{l}\text { More aimed at survival, short-term goals } \\
\text { become more important }\end{array}$ & \multirow{7}{*}{$4 / 13(31 \%)$} & \\
\hline & 16 & $\begin{array}{l}\text { Ethical business culture of own } \\
\text { company }\end{array}$ & No change & $\begin{array}{l}\text { Ethical business culture is fairly robust, and } \\
\text { ethics is even more important during a crisis } \\
\text { because of the difficult problems businesses } \\
\text { are facing }\end{array}$ & & \\
\hline & 17 & Criminal offences of own company & No change & $\begin{array}{l}\text { Historical evidence does not change due to } \\
\text { COVID-19 }\end{array}$ & & \\
\hline & 18 & $\begin{array}{l}\text { Corruption level country of own } \\
\text { company }\end{array}$ & No change & $\begin{array}{l}\text { Historical evidence does not change due to } \\
\text { COVID-19 }\end{array}$ & & \\
\hline & 19 & $\begin{array}{l}\text { Financial strains imposed on supplier by } \\
\text { own company }\end{array}$ & Increased vulnerability & More focus on own survival & & \\
\hline & 21 & Organizational strategy of supplier & Increased vulnerability & $\begin{array}{l}\text { More aimed at survival, short-term goals } \\
\text { become more important }\end{array}$ & & \\
\hline & 22 & Ethical business culture of supplier & No change & $\begin{array}{l}\text { Ethical business culture is fairly robust, and } \\
\text { ethics is even more important during a crisis } \\
\text { because of the difficult problems businesses } \\
\text { are facing }\end{array}$ & & \\
\hline
\end{tabular}




\begin{tabular}{|c|c|c|c|c|c|c|}
\hline $\begin{array}{l}\text { Fraud } \\
\text { risk } \\
\text { factor } \\
\text { category }\end{array}$ & $\begin{array}{l}\text { Fraud risk } \\
\text { factor } \\
\text { number }\end{array}$ & Fraud risk factor & $\begin{array}{l}\text { General change due to } \\
\text { Covid-19 outbreak }\end{array}$ & Justification & $\begin{array}{l}\text { Number of risk } \\
\text { factors affected per } \\
\text { fraud risk factor } \\
\text { category }(\%)\end{array}$ & $\begin{array}{l}\text { Number of risk } \\
\text { factors affected per } \\
\text { fraud risk key } \\
\text { element }(\%)\end{array}$ \\
\hline & 23 & Criminal offences of supplier & No change & $\begin{array}{l}\text { Historical evidence does not change due to } \\
\text { COVID-19 }\end{array}$ & & \\
\hline & 24 & Victimization of supplier & No change & $\begin{array}{l}\text { Historical evidence does not change due to } \\
\text { COVID-19 }\end{array}$ & & \\
\hline & 25 & Corruption level country of supplier & Increased vulnerability & $\begin{array}{l}\text { Supply may shift to more fraud-risky } \\
\text { locations due to limited supplies }\end{array}$ & & \\
\hline & 27 & Criminal offences of customer & No change & $\begin{array}{l}\text { Some companies may show additional non- } \\
\text { compliancy with COVID-19 rules }\end{array}$ & & \\
\hline & 28 & $\begin{array}{l}\text { Ethical business culture of branch of } \\
\text { industry }\end{array}$ & No change & $\begin{array}{l}\text { Ethical business culture is fairly robust, and } \\
\text { ethics is even more important during a crisis } \\
\text { because of the difficult problems businesses } \\
\text { are facing }\end{array}$ & & \\
\hline & 29 & Historical evidence in branch of industry & No change & $\begin{array}{l}\text { Historical evidence does not change due to } \\
\text { COVID-19 }\end{array}$ & & \\
\hline \multirow{6}{*}{ 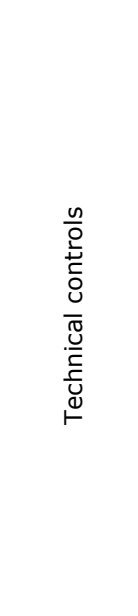 } & 32 & $\begin{array}{l}\text { Fraud monitoring system for raw } \\
\text { materials of own company }\end{array}$ & Increased vulnerability & $\begin{array}{l}\text { Priority of fraud monitoring has lowered in } \\
\text { survival mode, lower sampling and analysis } \\
\text { capacity }\end{array}$ & \multirow{6}{*}{$6 / 11(55 \%)$} & \\
\hline & 33 & $\begin{array}{l}\text { Verification of fraud monitoring system } \\
\text { for raw materials of own company }\end{array}$ & Increased vulnerability & $\begin{array}{l}\text { Priority of fraud monitoring has lowered in } \\
\text { survival mode, lower sampling and analysis } \\
\text { capacity }\end{array}$ & & \\
\hline & 34 & $\begin{array}{l}\text { Fraud monitoring system for final } \\
\text { products of own company }\end{array}$ & Increased vulnerability & $\begin{array}{l}\text { Priority of fraud monitoring has lowered in } \\
\text { survival mode, lower sampling and analysis } \\
\text { capacity }\end{array}$ & & \\
\hline & 35 & $\begin{array}{l}\text { Verification of fraud monitoring system } \\
\text { for final products of own company }\end{array}$ & Increased vulnerability & $\begin{array}{l}\text { Priority of fraud monitoring has lowered in } \\
\text { survival mode, lower sampling and analysis } \\
\text { capacity }\end{array}$ & & \\
\hline & 36 & Information system of own company & No change & Predominantly automated & & \\
\hline & 37 & $\begin{array}{l}\text { Tracking and tracing system of own } \\
\text { company }\end{array}$ & No change & Predominantly automated & & \\
\hline
\end{tabular}




\begin{tabular}{|c|c|c|c|c|c|c|}
\hline $\begin{array}{l}\text { Fraud } \\
\text { risk } \\
\text { factor } \\
\text { category }\end{array}$ & $\begin{array}{l}\text { Fraud risk } \\
\text { factor } \\
\text { number }\end{array}$ & Fraud risk factor & $\begin{array}{l}\text { General change due to } \\
\text { Covid-19 outbreak }\end{array}$ & Justification & $\begin{array}{l}\text { Number of risk } \\
\text { factors affected per } \\
\text { fraud risk factor } \\
\text { category }(\%)\end{array}$ & $\begin{array}{l}\text { Number of risk } \\
\text { factors affected per } \\
\text { fraud risk key } \\
\text { element }(\%)\end{array}$ \\
\hline & 42 & Fraud monitoring system of supplier & Increased vulnerability & $\begin{array}{l}\text { Priority of fraud monitoring has lowered in } \\
\text { survival mode, lower sampling and analysis } \\
\text { capacity }\end{array}$ & & \multirow{12}{*}{$12 / 19(63 \%)$} \\
\hline & 43 & Tracking and tracing system of supplier & No change & Predominantly automated & & \\
\hline & 44 & Tracking and tracing system of supplier & No change & Predominantly automated & & \\
\hline & 46 & Fraud control in sector & Increased vulnerability & No priority during crisis & & \\
\hline & 50 & Contingency plan & No change & $\begin{array}{l}\text { Existing protocols unlikely to change during } \\
\text { crisis }\end{array}$ & & \\
\hline \multirow{7}{*}{$\begin{array}{l}\frac{n}{0} \\
\frac{1}{0} \\
0 \\
\frac{0}{0} \\
\frac{\pi}{0} \\
\frac{0}{0} \\
0 \\
\frac{\pi}{0} \\
\frac{\pi}{2}\end{array}$} & 38 & Integrity screening of own employees & Increased vulnerability & No priority during crisis & \multirow{7}{*}{$6 / 8(75 \%)$} & \\
\hline & 39 & Ethical code of conduct of own company & No change & $\begin{array}{l}\text { Existing protocols unlikely to change during } \\
\text { crisis }\end{array}$ & & \\
\hline & 40 & $\begin{array}{l}\text { Whistle-blowing facilities of own } \\
\text { company }\end{array}$ & Increased vulnerability & $\begin{array}{l}\text { People have other priorities, work from home } \\
\text { (lowered visibility), and lower availability of } \\
\text { those collecting information }\end{array}$ & & \\
\hline & 41 & Contractual requirements of supplier & Increased vulnerability & $\begin{array}{l}\text { Requirements may be adapted due to } \\
\text { interruptions in supplies and demands }\end{array}$ & & \\
\hline & 45 & Social control in chain network & Increased vulnerability & $\begin{array}{l}\text { Social control is reduced due to working from } \\
\text { home (intra-business interactions) and fewer } \\
\text { inter-business interactions }\end{array}$ & & \\
\hline & 47 & National food policy & No change & $\begin{array}{l}\text { Existing legislation unlikely to change during } \\
\text { crisis }\end{array}$ & & \\
\hline & 48 & Law enforcement in local chain & Increased vulnerability & No priority during crisis & & \\
\hline
\end{tabular}




\begin{tabular}{|c|c|c|c|c|c|c|}
\hline $\begin{array}{l}\text { Fraud } \\
\text { risk } \\
\text { factor } \\
\text { category }\end{array}$ & $\begin{array}{l}\text { Fraud risk } \\
\text { factor } \\
\text { number }\end{array}$ & Fraud risk factor & $\begin{array}{l}\text { General change due to } \\
\text { CoVID-19 outbreak }\end{array}$ & Justification & $\begin{array}{l}\text { Number of risk } \\
\text { factors affected per } \\
\text { fraud risk factor } \\
\text { category }(\%)\end{array}$ & $\begin{array}{l}\text { Number of risk } \\
\text { factors affected per } \\
\text { fraud risk key } \\
\text { element }(\%)\end{array}$ \\
\hline & 49 & Law enforcement in chain network & Increased vulnerability & No priority during crisis & & \\
\hline
\end{tabular}

a Fraud risk factors originate from the SSAFE Food Fraud Vulnerability Assessment tool (van Ruth et al., 2017); Questions 7 and 8 are not included because they concern counterfeit products and do not apply to all chain networks. 


\section{Impact of the COVID-19 pandemic on specific industry segments}

The COVID-19 pandemic has disrupted supply and demand in food supply networks. Taking a spice, ginger, as an example, many effects can be distinguished. China is the largest exporter of ginger in the world but it was also hit first by COVID-19. This affected the production due to the lockdown and subsequent labour shortages. Furthermore, logistics were disrupted since most borders and countries were locked down, air freight was restricted and employees were self-isolating. This all resulted in a decrease in export during the first quarter of 2020. The inability of China to export the regular volumes of ginger resulted in disruption of supplies and price hikes. As a result, a kilogram of Chinese ginger which was US\$1.93 in late January 2020, soared temporarily to approximately US\$3.58 in February 2020. It also paved the way for other countries, such as Peru and Indonesia, to increase their ginger exports, leading to alternative paths and altered flows in the global ginger supply chain networks (Ayipey, 2020). Apart from the supply, the demand of ginger was affected too. During the lockdowns, home baking and sales of baking ingredients, such as flour, soared (Economist, 2020). Ginger demand rose too, but not only from baking enthusiasts. It increased too because of the belief that consumption of such a root crop could boost the human immune system irrespective of the World Health Organisation unapproved use of ginger as a traditional remedy to cure the virus (Ayipey, 2020). This example of ginger shows the roller coaster of supply and demand caused by the COVID-19 pandemic and the associated containment measures.

The rapid change in commodity price applies to most of the products under investigation in this report. A comparison between the global prices between the last quarter of 2019 and the second quarter of 2020 is presented in Table 4.1. Some showed a moderate price decrease $(<10 \%)$, such as eggs (EC, 2020), fish, and olive oil, whereas meats (beef, pork) and milk (IMF, 2020) showed a steeper price decline. In contrast, the price of bananas increased by $13 \%$ in the same period (IMF, 2020), whereas spices present a mixed picture depending on the type of spice (Commodity, 2020; Freshplaza, 2020).

For the current study, the disruptions in the food supply chain networks, which possibly impact on food fraud risks, have been divided in a number of aspects listed below. They were collated from various publications (Felix et al., 2020; Hobbs, 2020; Laborde et al., 2020; Reardon et al., 2020; Singh et al., 2020):

- $\quad$ Production/processing effects: Disruptions due to shortfall of staff and/or social distancing measures

- Logistics:

- Export disruptions

- Import disruptions

- Excessive storage

- Demand:

- Decrease due to the impact of closure of food service

- Increase due to panic buying, home cooking, or for health reasons

The anticipated relevance of these aspects for the supply chain networks in regular productions (fish, meat (beef), milk, olive oil, spices) and organic productions (banana, egg, olive oil, meat (pork)) are indicated in Table 4.2. All supply chain networks are affected to a smaller or larger extent. Meat (beef) supply chain networks appear to be impacted by the largest number of different aspects, followed by the fish supply chain networks. From the above, considering both the impact of supply and demand disruptions as well as the derived price effects, the animal product supply chains (fish, meat, milk) appear the most affected by the COVID-19 pandemic. 
Table 4.1 Prices of commodities (US $\$ \mathrm{~kg}^{-1}$ ) and relative changes between the forth quarter of 2019 and the second quarter of $2020^{a}$.

\begin{tabular}{|l|c|c|c|}
\hline \multicolumn{1}{|c|}{ Commodity } & Price 2019-Q4 & Change [\%] \\
\hline Bananas $^{\mathrm{b}}$ & 1.14 & 1.29 & +13 \\
\hline Eggs $^{\mathrm{c}}$ & 1.67 & 1.56 & -7 \\
\hline Fish $^{\mathrm{b}}$ & 6.50 & 6.10 & -6 \\
\hline Meat (beef) $^{\mathrm{b}}$ & 5.30 & 4.60 & -13 \\
\hline Meat (pork) $^{\mathrm{b}}$ & 1.29 & 1.16 & -10 \\
\hline Milk $^{\mathrm{b}}$ & 0.43 & 0.33 & -23 \\
\hline Olive oil $^{\mathrm{b}}$ & 2.92 & 2.79 & -4 \\
\hline Spices (coriander) & 0.93 & 0.80 & -14 \\
Spices (ginger) $^{\mathrm{d}}$ & 1.70 & 1.80 & +6 \\
\hline
\end{tabular}

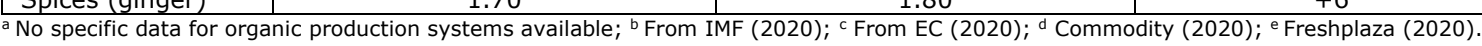

Table 4.2 Expected impact of production, logistics' and demand disruption factors ${ }^{a}$ on food industry segments.

\begin{tabular}{|c|c|c|c|c|c|c|}
\hline Commodity & $\begin{array}{l}\text { Production/ } \\
\text { processing : } \\
\text { Disruptions } \\
\text { due to } \\
\text { shortfall of } \\
\text { staff and/or } \\
\text { social } \\
\text { distancing } \\
\text { measures }\end{array}$ & $\begin{array}{l}\text { Logistics: } \\
\text { Export } \\
\text { disruptions }\end{array}$ & $\begin{array}{l}\text { Logistics: } \\
\text { Import } \\
\text { disruptions }\end{array}$ & $\begin{array}{l}\text { Logistics: } \\
\text { Excessive } \\
\text { storage }\end{array}$ & $\begin{array}{l}\text { Demand: } \\
\text { Decrease due } \\
\text { to the impact } \\
\text { of closure of } \\
\text { food service }\end{array}$ & $\begin{array}{l}\text { Demand: } \\
\text { Increase due } \\
\text { to panic } \\
\text { buying, home } \\
\text { cooking, or } \\
\text { for health } \\
\text { reasons }\end{array}$ \\
\hline Meat (beef) & $x$ & $x$ & & $x$ & $x$ & \\
\hline Milk & & $x$ & & $x$ & & \\
\hline Olive oil & & & $x$ & & & $x$ \\
\hline Organic egg & & $x$ & & & & $x$ \\
\hline Organic olive oil & & & $x$ & & & \\
\hline $\begin{array}{l}\text { Organic meat } \\
\text { (pork) }\end{array}$ & $x$ & $x$ & & & & \\
\hline
\end{tabular}

a Collated from: Felix et al., 2020; Hobbs, 2020; Laborde et al., 2020; Reardon et al., 2020; Singh et al., 2020. 


\section{$5 \quad$ Merging baseline fraud vulnerabilities in industry segments with expected impact of the COVID-19 pandemic}

From the empirical data in Section 2 of this report, it is obvious that industry segments differ in their baseline fraud vulnerability levels and that these are mostly caused by differences in the level of opportunities and motivations. In the industry segments investigated, in particular the meat, olive oil, and spice supply chain networks appeared more vulnerable than others (Fig. 5.1). The COVID-19 pandemic appears to enhance food fraud vulnerability by altering in particular the degree of economic and cultural/behavioural drivers (motivations). Opportunities are affected to a lesser extent by the pandemic (Section 3). This shift is represented in Fig. 5.1 by the orange arrow. Control systems start to show some cracks to some extent as well. When examining the impact of the COVID-19 pandemic on production, logistics, and demand disruptions, all industry segments show impact on at least two of these aspects (Section 4). Even so, the fish and meat supply chain networks appear to be affected at most fronts. On the other hand, looking at economic impact, which relates to the change in degree of economic drivers, meat and milk supply chain networks are affected to the largest extent. Combining this information, olive oil, meat, and spice supply chain networks remain highly vulnerable to food fraud, with the largest increase in food fraud vulnerability expected for animal product supply chain networks.

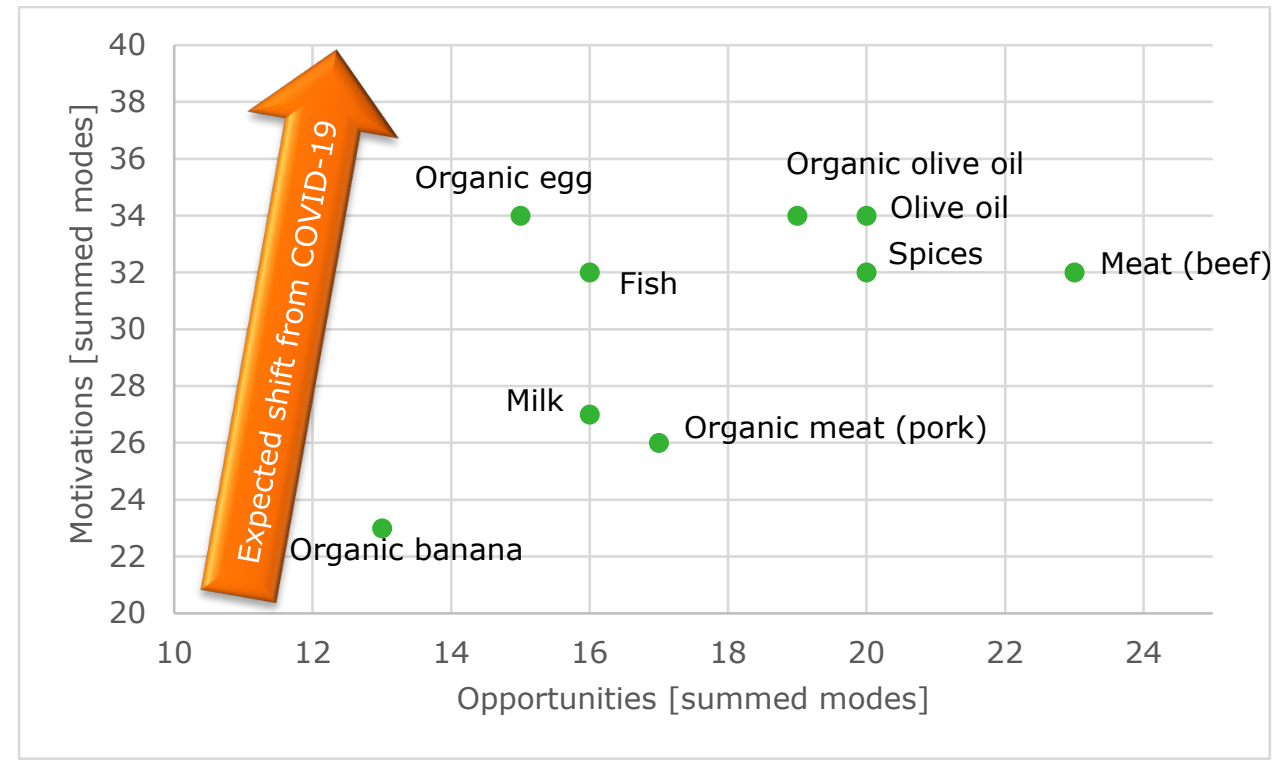

Figure 5.1 Food fraud vulnerability levels for drivers and enablers in various food industries represented for opportunities (horizontal) and motivations (vertical): Summed modes for individual fraud risk factors, raw data is listed in Annex 1. Higher scores reflect higher vulnerability. 


\section{Conclusions}

Industry segments differ intrinsically in their levels of fraud vulnerability. They differ primarily in their degree in opportunities and motivations, and to a lesser extent in their levels of control. The COVID19 pandemic increases fraud vulnerability considerably, with nearly half of the fraud risk factors being negatively affected. The pandemic affects mostly food fraud vulnerability through enhanced economic and cultural/behavioural drivers and to a lesser extent through increased opportunities. Furthermore, counteracting control systems show cracks due to the pandemic. The pandemic results in disruptions in production, logistics, and demand, which in turn affect primarily the economic and

cultural/behavioural drivers. Most widely spread effects are expected for the animal production chain networks, with fraud vulnerability of these networks, which had a high baseline prior to the pandemic already, further increasing. 


\section{References}

Ayipey, P., 2020. Impact of Covid-19 on ginger export, a root crop as traditional remedy for Covid-19. Journal of Basic and Applied Biomedicine 6: 25-31.

Cohen, L. E., and M. Felson, 1979. Social change and crime rate trends: A routine activity approach. American Sociological Review 44: 588-608.

Commodity, 2020. URL: https://www.commodityonline.com.

Deloitte, 2020. The impact of COVID-19 on the fraud risks faced by organisations. URL: https://www2.deloitte.com/content/dam/Deloitte/pl/Documents/Brochures/pl_COVID_19_Fraud\% 20Risks_EN_newApril2020.pdf.

EC, 2020. URL: https://ec.europa.eu/info/food-farming-fisheries/farming/facts-andfigures/markets/prices/price-monitoring-sector_en.

Economist, 2020. URL: https://www.economist.com/graphic-detail/2020/04/08/home-baking-is-onthe-rise-thanks-to-coronavirus-lockdowns.

Freshplaza, 2020. URL: https://www.freshplaza.com.

IMF, 2020. URL: https://indexmundi.com.

Felix, I., Martin, A., Mehta, V., and C. Mueller, 2020. US food supply chain: Disruptions and implications from COVID-19. URL: https://www.mckinsey.com/industries/consumer-packagedgoods/our-insights/us-food-supply-chain-disruptions-and-implications-from-covid-19\#

Hobbs, J. E., 2020. Food supply chains during the COVID-19 pandemic. Canadian Journal of Agricultural Economics 68: 171-176.

Laborde, D., Martin, W., Swinnen, J., and R. Vos, 2020. COVID-19 risks to global food security. Science 369: 6503.

Reardon, T., Bellemare, M. F., and D. Zilberman, 2020. How COVID-19 may disrupt food supply chains in developing countries. In: COVID-19 and global food security, Chapter 17, International Food Policy Research Institute: 78-80.

Robson, K., Dean, M., Brooks, S., Haughey, S., and C. Elliott, 2020. A 20-year analysis of reported food fraud in the global beef supply chain. Food Control 116: 107310.

Silvis, I. C. J., van Ruth, S. M., van der Fels-Klerx, H. J., and P. A. Luning, 2017. Assessment of food fraud vulnerability in the spices chain: An explorative study. Food Research International 133: 109158.

Singh, S., Kumar, R., Panchal, R., and T. Manoj Kumar, 2020. Impact of COVID-19 on logistics systems and disruptions in food supply chain. International Journal of Production Research, DOI: 10.1080/00207543.2020.1792000.

SSAFE, 2020. URL: www.SSAFE-food.org.

van Ruth, S. M., and L. Pagter-de Witte, 2020. Integrity of organic foods and their suppliers: Fraud vulnerability across chains. Foods 9: 188.

van Ruth, S. M., Huisman, W., and P. A. Luning, 2017. Food fraud vulnerability and its key factors. Trends in Food Science and Technology 67: 70-75.

van Ruth, S. M., Luning, P. A., Silvis, I. C. J., Yang, Y., and W. Huisman, 2018. Differences in fraud vulnerability in various food supply chains and their tiers. Food Control 84: 375-381.

Wu, Y. -N., Zhao, Y. -F., and J. -G. Li, 2009. A survey on occurrence of melamine and its analogues in tainted infant formula in China. Biomedical and Environmental Sciences 22: 95-99.

Yan, J., Erasmus, S. W., Aguilera Toro, M., Huang, H., and S. M. van Ruth, 2020. Food fraud: Assessing fraud vulnerability in the extra virgin olive oil supply chain. Food Control 111: 107081.

Yang, Y., Huisman, W., Hettinga, K. A., Liu, N., Heck, J., Schrijver, G. H., Gaiardoni, L., and S. M. van Ruth, 2019. Fraud vulnerability in the Dutch milk supply chain: Assessments of farmers, processors and retailers. Food Control 95: 308-317. 


\section{Annex 1 Modes of vulnerability scores of businesses in various food industry segments for individual food fraud risk factors ${ }^{a}$.}

\begin{tabular}{|c|c|c|c|c|c|c|c|c|c|c|c|}
\hline $\begin{array}{l}\text { Fraud } \\
\text { risk } \\
\text { factor } \\
\text { category }\end{array}$ & $\begin{array}{l}\text { Fraud } \\
\text { risk } \\
\text { factor } \\
\text { number }\end{array}$ & Fraud risk factor & $\begin{array}{l}\text { Fish } \\
(n=5) \\
\end{array}$ & $\begin{array}{c}\text { Meat } \\
\text { (beef) } \\
(n=5) \\
\end{array}$ & $\begin{array}{l}\text { Milk } \\
(n=8) \\
\end{array}$ & $\begin{array}{l}\text { Olive oil } \\
(n=8)\end{array}$ & $\begin{array}{l}\text { Spices } \\
(n=8) \\
\end{array}$ & $\begin{array}{c}\begin{array}{c}\text { Organic } \\
\text { banana }\end{array} \\
(n=5)\end{array}$ & $\begin{array}{l}\text { Organic } \\
\text { egg } \\
(n=5)\end{array}$ & $\begin{array}{l}\text { Organic } \\
\text { meat } \\
\text { (pork) } \\
(n=5)\end{array}$ & $\begin{array}{l}\text { Organic } \\
\text { olive oil } \\
(n=5)\end{array}$ \\
\hline \multirow{5}{*}{ 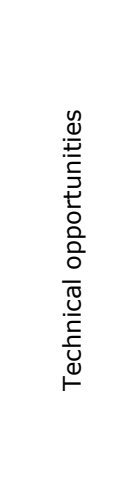 } & 1 & $\begin{array}{l}\text { Complexity adulteration raw } \\
\text { materials }\end{array}$ & 1 & 2 & 2 & 2 & 3 & 1 & 1 & 3 & 3 \\
\hline & 2 & $\begin{array}{l}\text { Availability of technology and } \\
\text { knowledge to adulterate raw } \\
\text { materials }\end{array}$ & 1 & 3 & 3 & 2 & 3 & 1 & 2 & 1 & 3 \\
\hline & 3 & $\begin{array}{l}\text { Fraud detectability in raw } \\
\text { materials }\end{array}$ & 1 & 3 & 2 & 3 & 2 & 2 & 2 & 3 & 3 \\
\hline & 4 & $\begin{array}{l}\text { Availability of technology and } \\
\text { knowledge to adulterate final } \\
\text { products }\end{array}$ & 3 & 2 & 3 & 2 & 3 & 3 & 1 & 2 & 3 \\
\hline & 5 & $\begin{array}{l}\text { Fraud detectability in final } \\
\text { products }\end{array}$ & 3 & 3 & 2 & 3 & 2 & 2 & 2 & 3 & 3 \\
\hline \multirow{4}{*}{ 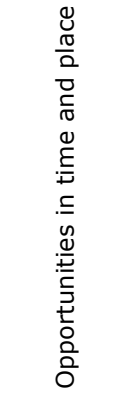 } & 8 & $\begin{array}{l}\text { Access to production } \\
\text { lines/processing activities }\end{array}$ & 2 & 3 & 1 & 1 & 1 & 1 & 1 & 2 & 1 \\
\hline & 9 & $\begin{array}{l}\text { Transparency in the chain } \\
\text { network }\end{array}$ & 2 & 1 & 1 & 2 & 2 & 1 & 2 & 1 & 1 \\
\hline & 10 & $\begin{array}{l}\text { Historical evidence of fraud in } \\
\text { raw materials }\end{array}$ & 1 & 3 & 1 & 3 & 2 & 1 & 2 & 1 & 1 \\
\hline & 11 & $\begin{array}{l}\text { Historical evidence of fraud in } \\
\text { final products }\end{array}$ & 2 & 3 & 1 & 2 & 2 & 1 & 2 & 1 & 1 \\
\hline
\end{tabular}




\begin{tabular}{|c|c|c|c|c|c|c|c|c|c|c|c|}
\hline $\begin{array}{l}\text { Fraud } \\
\text { risk } \\
\text { factor } \\
\text { category }\end{array}$ & $\begin{array}{l}\text { Fraud } \\
\text { risk } \\
\text { factor } \\
\text { number }\end{array}$ & Fraud risk factor & $\begin{array}{l}\text { Fish } \\
(n=5) \\
\end{array}$ & $\begin{array}{r}\text { Meat } \\
\text { (beef) } \\
(n=5) \\
\end{array}$ & $\begin{array}{l}\text { Milk } \\
(n=8) \\
\end{array}$ & $\begin{array}{l}\text { Olive oil } \\
(n=8)\end{array}$ & $\begin{array}{l}\text { Spices } \\
(n=8) \\
\end{array}$ & $\begin{array}{c}\begin{array}{c}\text { Organic } \\
\text { banana }\end{array} \\
(n=5)\end{array}$ & $\begin{array}{l}\text { Organic } \\
\text { egg } \\
(n=5)\end{array}$ & $\begin{array}{l}\text { Organic } \\
\text { meat } \\
\text { (pork) } \\
(n=5)\end{array}$ & $\begin{array}{l}\text { Organic } \\
\text { olive oi } \\
(n=5)\end{array}$ \\
\hline \multirow{7}{*}{ 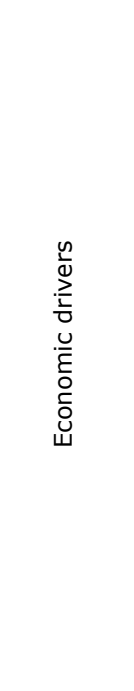 } & 12 & Supply and pricing raw materials & 2 & 1 & 2 & 2 & 3 & 1 & 1 & 1 & 3 \\
\hline & 13 & $\begin{array}{l}\text { Valuable components or } \\
\text { attributes }\end{array}$ & 1 & 3 & 3 & 3 & 3 & 1 & 3 & 1 & 3 \\
\hline & 14 & $\begin{array}{l}\text { Economic health of own } \\
\text { company }\end{array}$ & 1 & 1 & 1 & 1 & 1 & 1 & 1 & 1 & 1 \\
\hline & 20 & Economic health of supplier & 2 & 1 & 1 & 2 & 1 & 1 & 2 & 1 & 2 \\
\hline & 26 & Economic health of sector & 2 & 2 & 3 & 2 & 2 & 1 & 1 & 1 & 1 \\
\hline & 30 & $\begin{array}{l}\text { Level of competition in branch of } \\
\text { industry }\end{array}$ & 2 & 3 & 2 & 3 & 2 & 3 & 3 & 1 & 3 \\
\hline & 31 & Price asymmetries & 1 & 3 & 2 & 1 & 3 & 1 & 3 & 1 & 2 \\
\hline \multirow{5}{*}{ 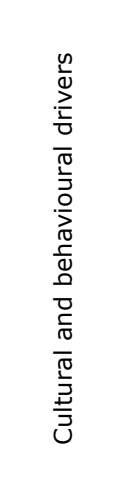 } & 15 & $\begin{array}{l}\text { Organizational strategy of own } \\
\text { company }\end{array}$ & 1 & 1 & 1 & 1 & 1 & 1 & 1 & 1 & 1 \\
\hline & 16 & $\begin{array}{l}\text { Ethical business culture of own } \\
\text { company }\end{array}$ & 1 & 1 & 1 & 1 & 1 & 1 & 1 & 1 & 1 \\
\hline & 17 & $\begin{array}{l}\text { Criminal offences of own } \\
\text { company }\end{array}$ & 1 & 1 & 1 & 1 & 1 & 1 & 2 & 1 & 1 \\
\hline & 18 & $\begin{array}{l}\text { Corruption level country of own } \\
\text { company }\end{array}$ & 1 & 1 & 1 & 1 & 3 & 1 & 1 & 1 & 1 \\
\hline & 19 & $\begin{array}{l}\text { Financial strains imposed on } \\
\text { supplier by own company }\end{array}$ & 2 & 1 & 1 & 2 & 1 & 1 & 2 & 1 & 1 \\
\hline
\end{tabular}




\begin{tabular}{|c|c|c|c|c|c|c|c|c|c|c|c|}
\hline $\begin{array}{l}\text { Fraud } \\
\text { risk } \\
\text { factor } \\
\text { category }\end{array}$ & $\begin{array}{l}\text { Fraud } \\
\text { risk } \\
\text { factor } \\
\text { number }\end{array}$ & Fraud risk factor & $\begin{array}{l}\text { Fish } \\
(n=5) \\
(n+10\end{array}$ & $\begin{array}{l}\text { Meat } \\
\text { (beef) } \\
(n=5)\end{array}$ & $\begin{array}{l}\text { Milk } \\
(n=8) \\
\end{array}$ & $\begin{array}{l}\text { Olive oil } \\
(n=8)\end{array}$ & $\begin{array}{l}\text { Spices } \\
(n=8) \\
(n=8\end{array}$ & $\begin{array}{l}\begin{array}{c}\text { Organic } \\
\text { banana }\end{array} \\
(n=5)\end{array}$ & $\begin{array}{l}\text { Organic } \\
\text { egg } \\
(n=5)\end{array}$ & $\begin{array}{l}\text { Organic } \\
\text { meat } \\
\text { (pork) } \\
(n=5)\end{array}$ & $\begin{array}{l}\text { Organic } \\
\text { olive oil } \\
(n=5)\end{array}$ \\
\hline & 21 & $\begin{array}{l}\text { Organizational strategy of } \\
\text { supplier }\end{array}$ & 2 & 1 & 1 & 2 & 1 & 1 & 2 & 1 & 2 \\
\hline & 22 & $\begin{array}{l}\text { Ethical business culture of } \\
\text { supplier }\end{array}$ & 2 & 1 & 1 & 2 & 2 & 1 & 1 & 1 & 2 \\
\hline & 23 & Criminal offences of supplier & 2 & 2 & 1 & 1 & 1 & 1 & 1 & 3 & 1 \\
\hline & 24 & Victimization of supplier & 2 & 2 & 1 & 1 & 1 & 1 & 1 & 3 & 1 \\
\hline & 25 & $\begin{array}{l}\text { Corruption level country of } \\
\text { supplier }\end{array}$ & 1 & 2 & 1 & 2 & 1 & 2 & 2 & 1 & 2 \\
\hline & 27 & Criminal offences of customer & 2 & 2 & 1 & 2 & 1 & 1 & 1 & 1 & 1 \\
\hline & 28 & $\begin{array}{l}\text { Ethical business culture of } \\
\text { branch of industry }\end{array}$ & 2 & 1 & 1 & 2 & 2 & 1 & 2 & 1 & 3 \\
\hline & 29 & $\begin{array}{l}\text { Historical evidence in branch of } \\
\text { industry }\end{array}$ & 2 & 2 & 1 & 2 & 1 & 1 & 3 & 3 & 2 \\
\hline \multirow{4}{*}{ 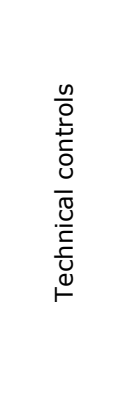 } & 32 & $\begin{array}{l}\text { Fraud monitoring system for raw } \\
\text { materials of own company }\end{array}$ & 1 & 1 & 3 & 2 & 1 & 2 & 3 & 1 & 3 \\
\hline & 33 & $\begin{array}{l}\text { Verification of fraud monitoring } \\
\text { system for raw materials of own } \\
\text { company }\end{array}$ & 2 & 1 & 3 & 3 & 3 & 2 & 3 & 1 & 2 \\
\hline & 34 & $\begin{array}{l}\text { Fraud monitoring system for } \\
\text { final products of own company }\end{array}$ & 3 & 1 & 3 & 3 & 3 & 2 & 3 & 2 & 3 \\
\hline & 35 & $\begin{array}{l}\text { Verification of fraud monitoring } \\
\text { system for final products of own } \\
\text { company }\end{array}$ & 3 & 2 & 3 & 3 & 3 & 3 & 3 & 3 & 3 \\
\hline
\end{tabular}




\begin{tabular}{|c|c|c|c|c|c|c|c|c|c|c|c|}
\hline $\begin{array}{l}\text { Fraud } \\
\text { risk } \\
\text { factor } \\
\text { category }\end{array}$ & $\begin{array}{l}\text { Fraud } \\
\text { risk } \\
\text { factor } \\
\text { number }\end{array}$ & Fraud risk factor & $\begin{array}{l}\text { Fish } \\
(n=5) \\
\end{array}$ & $\begin{array}{l}\text { Meat } \\
\text { (beef) } \\
(n=5) \\
\end{array}$ & $\begin{array}{l}\text { Milk } \\
(n=8) \\
\end{array}$ & $\begin{array}{l}\text { Olive oil } \\
(n=8) \\
\end{array}$ & $\begin{array}{l}\text { Spices } \\
(n=8) \\
\end{array}$ & $\begin{array}{l}\begin{array}{c}\text { Organic } \\
\text { banana }\end{array} \\
(n=5)\end{array}$ & $\begin{array}{l}\text { Organic } \\
\text { egg } \\
(n=5)\end{array}$ & $\begin{array}{l}\text { Organic } \\
\text { meat } \\
\text { (pork) } \\
(n=5)\end{array}$ & $\begin{array}{l}\begin{array}{l}\text { Organic } \\
\text { olive oil } \\
(n=5) \\
\end{array} \\
\end{array}$ \\
\hline & 36 & $\begin{array}{l}\text { Information system of own } \\
\text { company }\end{array}$ & 1 & 2 & 1 & 3 & 1 & 3 & 3 & 2 & 3 \\
\hline & 37 & $\begin{array}{l}\text { Tracking and tracing system of } \\
\text { own company }\end{array}$ & 1 & 2 & 2 & 3 & 1 & 2 & 3 & 2 & 3 \\
\hline & 42 & $\begin{array}{l}\text { Fraud monitoring system of } \\
\text { supplier }\end{array}$ & 2 & 2 & 2 & 2 & 3 & 2 & 3 & 3 & 2 \\
\hline & 43 & $\begin{array}{l}\text { Tracking and tracing system of } \\
\text { supplier }\end{array}$ & 2 & 2 & 2 & 2 & 3 & 2 & 3 & 3 & 2 \\
\hline & 44 & $\begin{array}{l}\text { Tracking and tracing system of } \\
\text { supplier }\end{array}$ & 2 & 1 & 1 & 2 & 3 & 2 & 3 & 2 & 2 \\
\hline & 46 & Fraud control in sector & 3 & 3 & 2 & 2 & 3 & 3 & 2 & 2 & 3 \\
\hline & 50 & Contingency plan & 2 & 2 & 2 & 1 & 3 & 2 & 3 & 3 & 2 \\
\hline \multirow{5}{*}{ 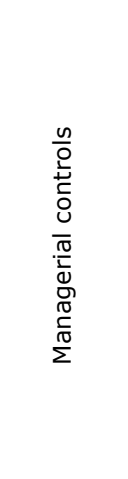 } & 38 & $\begin{array}{l}\text { Integrity screening of own } \\
\text { employees }\end{array}$ & 3 & 3 & 1 & 2 & 3 & 2 & 2 & 3 & 1 \\
\hline & 39 & $\begin{array}{l}\text { Ethical code of conduct of own } \\
\text { company }\end{array}$ & 3 & 1 & 1 & 2 & 1 & 3 & 1 & 3 & 3 \\
\hline & 40 & $\begin{array}{l}\text { Whistle-blowing facilities of own } \\
\text { company }\end{array}$ & 3 & 1 & 1 & 3 & 3 & 3 & 1 & 3 & 1 \\
\hline & 41 & $\begin{array}{l}\text { Contractual requirements of } \\
\text { supplier }\end{array}$ & 2 & 1 & 2 & 2 & 3 & 2 & 1 & 3 & 2 \\
\hline & 45 & Social control in chain network & 2 & 2 & 2 & 2 & 2 & 2 & 2 & 2 & 2 \\
\hline
\end{tabular}




\begin{tabular}{|c|c|c|c|c|c|c|c|c|c|c|c|}
\hline $\begin{array}{l}\text { Fraud } \\
\text { risk } \\
\text { factor } \\
\text { category }\end{array}$ & $\begin{array}{l}\text { Fraud } \\
\text { risk } \\
\text { factor } \\
\text { number }\end{array}$ & Fraud risk factor & $\begin{array}{l}\text { Fish } \\
(n=5) \\
\end{array}$ & 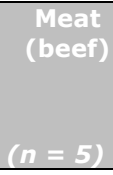 & $\begin{array}{l}\text { Milk } \\
(n=8) \\
\end{array}$ & $\begin{array}{l}\text { Olive oil } \\
(n=8)\end{array}$ & $\begin{array}{l}\text { Spices } \\
(n=8) \\
\end{array}$ & $\begin{array}{c}\begin{array}{c}\text { Organic } \\
\text { banana }\end{array} \\
(n=5)\end{array}$ & $\begin{array}{l}\text { Organic } \\
\text { egg } \\
(n=5)\end{array}$ & $\begin{array}{l}\text { Organic } \\
\text { meat } \\
\text { (pork) } \\
(n=5)\end{array}$ & $\begin{array}{l}\text { Organic } \\
\text { olive oil } \\
(n=5)\end{array}$ \\
\hline & 47 & National food policy & 3 & 3 & 3 & 2 & 3 & 3 & 2 & 2 & 3 \\
\hline & 48 & Law enforcement in local chain & 2 & 2 & 3 & 2 & 3 & 2 & 1 & 2 & 2 \\
\hline & 49 & $\begin{array}{l}\text { Law enforcement in chain } \\
\text { network }\end{array}$ & 2 & 2 & 3 & 2 & 3 & 2 & 2 & 2 & 2 \\
\hline
\end{tabular}

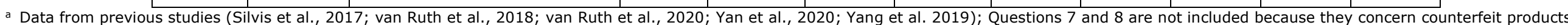
and do not apply to all supply chain networks. 
Wageningen Food Safety Research P.O. Box 230

6700 AE Wageningen

The Netherlands

$\mathrm{T}+31(0) 317480256$

www.wur.eu/food-safety-research

WFSR report 2020.017
The mission of Wageningen University \& Research is "To explore the potential of nature to improve the quality of life". Under the banner Wageningen University \& Research, Wageningen University and the specialised research institutes of the Wageningen Research Foundation have joined forces in contributing to finding solutions to important questions in the domain of healthy food and living environment. With its roughly 30 branches, 6,500 employees (5,500 fte) and 12,500 students, Wageningen University \& Research is one of the leading organisations in its domain. The unique Wageningen approach lies in its integrated approach to issues and the collaboration between different disciplines. 